\title{
Senegal: Train more providers in postabortion care
}

Frontiers in Reproductive Health

Follow this and additional works at: https://knowledgecommons.popcouncil.org/departments_sbsr-rh

Part of the International Public Health Commons, Public Health Education and Promotion Commons, and the Women's Health Commons How does access to this work benefit you? Let us know!

\section{Recommended Citation}

"Senegal: Train more providers in postabortion care," FRONTIERS OR Summary. Washington, DC:

Population Council, 2000. 


\section{Senegal Postabortion Care}

\author{
OR Summary 4
}

\section{Train More Providers in Postabortion Care}

\begin{abstract}
Improving postabortion care $(P A C)$ services benefits patients and reduces costs. Providing PAC services can result in shorter hospital stays, decreased patient costs, better communication between providers and patients, and increased acceptance of contraceptive use by women treated for abortion or miscarriage. Local anesthesia is needed for pain control.
\end{abstract}

\section{Background}

In Senegal, nearly one in five women requiring emergency obstetrical care has had a nonmedical abortion. Recognizing unsafe abortion as a serious health problem, the government adopted a national health strategy in 1997 that aims to halve the number of unsafe abortion cases by the year 2001.

In 1997 the Center for Training and Research in Reproductive Health (CEFOREP) and the Obstetrics and Gynecology Clinic (CGO) at Le Dantec University Teaching Hospital in Dakar introduced new clinical techniques to improve emergency treatment for women with complications from miscarriage or abortion. The CGO and two other teaching hospitals served as pilot sites. Physicians, nurses and midwives at the three sites received training in manual vacuum aspiration (MVA), family planning, and counseling. The United Nations Population Fund and JHPIEGO Corporation provided equipment, logistics support and training.

To measure the impact of the training, CEFOREP interviewed 320 women receiving emergency treatment and 204 providers before the intervention and 543 patients and 175 providers after the intervention. Information on service delivery costs was also collected.

\section{Findings}

- After training, providers quickly shifted to MVA from other clinical techniques.

- Changes in service management reduced hospital stays by nearly half, to an average of 1.2 days. Patient costs dropped by 25 percent, although the cost (CFA 26,700 or US\$46) remains high for these patients (see Table).

\section{Expanding access to PAC and improving referral procedures could save more women's lives.}

- Communication between providers and patients improved. Patients received more information about the treatment and more psychological support. However, verbal reassurances did not reduce the need for local anesthesia for pain control.

- After the intervention, the proportion of patients who received family planning counseling doubled. Of those who were counseled, the proportion of women who decided to use a contraceptive method increased from 56 percent to 76 percent. 


\section{Policy Implications}

- Expanding access to PAC and improving referral procedures could save more women's lives. More than two in three of all patients interviewed had visited two or more hospitals before receiving treatment, delaying care for up to 4.7 days from the onset of symptoms.
- PAC training should be extended to more physicians, midwives and nurses. Pain control medication is essential. PAC supplies and equipment should be included in hospital and clinic budgets.

- FP counseling should be systematically provided to all postabortion patients.

\section{Benefits of Improved PAC Services}

\begin{tabular}{lcc}
\hline & $\begin{array}{c}\text { Before } \\
\text { Training }\end{array}$ & $\begin{array}{c}\text { After } \\
\text { Training }\end{array}$ \\
\hline $\begin{array}{l}\text { Patients admitted immediately for } \\
\text { treatment }\end{array}$ & $55 \%$ & $69 \%$ \\
\hline $\begin{array}{l}\text { Length of hospital stay-2 hospitals } \\
\text { Cost to patient }\end{array}$ & 2.3 days & 1.2 days \\
\hline Patients counseled about family planning & $\begin{array}{c}18 \%, 800 \mathrm{CFA} \\
(\mathrm{US} \$ 61)\end{array}$ & $\begin{array}{c}26,700 \mathrm{CFA} \\
\text { (US } \$ 46)\end{array}$ \\
\hline $\begin{array}{l}\text { Of patients counseled, those who received } \\
\text { a contraceptive }\end{array}$ & $56 \%$ & $34 \%$ \\
\hline
\end{tabular}

Centre de Formation et de Recherche en Santé de la Reproduction and Clinique Gynecologique et Obstetricale Chu A. le Dantec, 1998. Introduction des Soins Obstetricaux d'Urgence et de la Planification Familiale pour les Patientes Presentant des Complications Lieés a un Avortement Incomplet. For more information, contact: Population Council, 128 Sotrac Mermoz, P.O. Box 21027, Dakar, Senegal.Tel.221-824-1993; Fax: 221-824-1998; E-mail: pcdakar@pcdakar.org.

This project was conducted with support from the U.S. AGENCY FOR INTERNATIONAL DEVELOPMENT under Contract Number CCP-3030-C-00-3008-00 and Cooperative Agreement Number HRN-A-00-98-00012-00. 